Miloš D. Đorđević

Research Assistant University of Belgrade

Faculty of Mechanical Engineering

Goran M. Mladenović

Assistant Professor University of Belgrade

Faculty of Mechanical Engineering

Nenad Đ. Zrnić

Professor

University of Belgrade

Faculty of Mechanical Engineering

Srđan M. Bošnjak

Professor

University of Belgrade

Faculty of Mechanical Engineering

\section{LCA of the Manufacturing Stage of the Laboratory Belt Conveyor}

A cradle-to-gate LCA analysis of a small belt conveyor was conducted. Manufacturing stage was analysed from the aspects of environmental impacts and energy consumption. The biggest environmental impact in majority of baseline impact categories is obtained from low-alloyed steel production and electricity consumption during the manufacturing stage, followed by impact of the transport. Ways for possible energy savings regarding manufacturing practice and technologies were proposed later on.

Keywords: Life cycle assessment, cradle-to-gate, belt conveyor, life cycle thinking, SimaPro 8, production, energy efficiency, environmental impact.

\section{INTRODUCTION}

The purpose of this paper is to provide an insight into possible environmental improvements of production stage of small belt conveyors, produced in small series. The study is based on the Life Cycle Assessment (LCA) of a single belt conveyor for special purpose. This belt conveyor is part of a laboratory test facility for Nondestructive Testing (NDT) of steel cord belts.

The facility consists of several different modules (see Fig. 1):

1. Belt conveyor - main module

2. Belt conveyor mobile carrier frame

3. Scanner girder - for NDT of steel cord belts

4. Belt conveyor skirt boards - for investigation of bulk material properties and behaviour

5. Belt conveyor girder - for mounting of the belt conveyor on the portal crane (Fig. 2) and investigations of the crane vibrations.

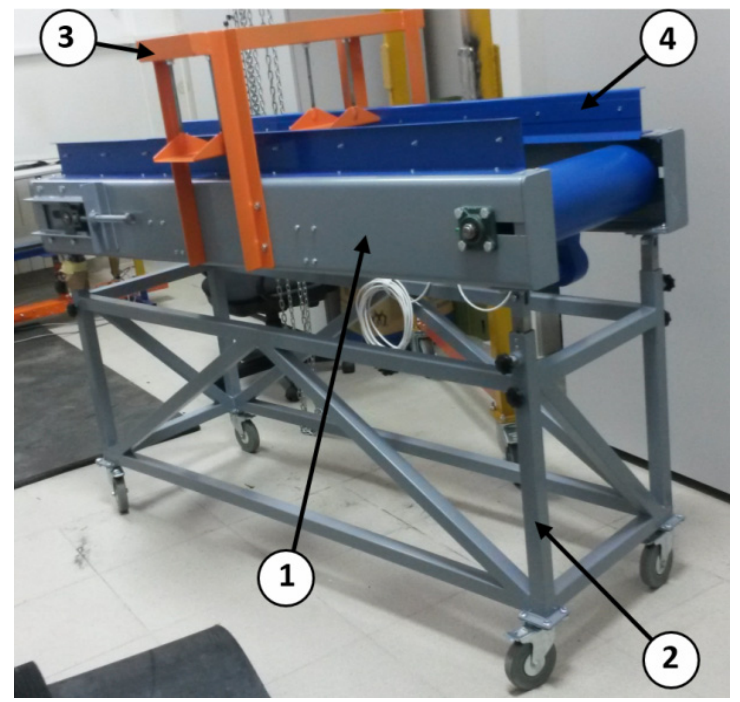

Figure 1. Four modules of the test facility

Received: January 2018, Accepted: March 2018

Correspondence to: Miloš Đorđević, research assistant

Faculty of Mechanical Engineering,

Kraljice Marije 16, 11120 Belgrade 35, Serbia

E-mail: mddjordjevic@mas.bg.ac.rs

doi:10.5937/fmet1803410D

(C) Faculty of Mechanical Engineering, Belgrade. All rights reserved

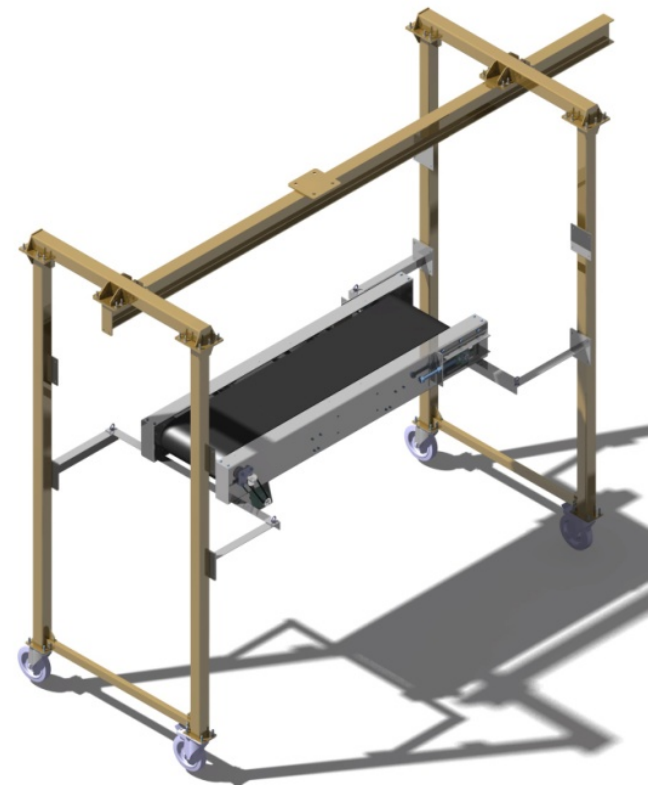

Figure 2. Belt conveyor mounted on the portal crane using specially designed girders

Some of these modules are described in more detail in [1] and [2]. The scanner girder and belt conveyor girder modules have been excluded from the analysis.

Conducted LCA represents a cradle-to-gate analysis. It is performed using SimaPro 8 Educational software package [3]. The analysis is focused on the production stage of the belt conveyor. Use phase and the end of life phase are not modelled.

As already explained in [4], [5] and [6], in accordance with EN ISO 14040: 2006 [7], life cycle consists of 5 consecutive stages:

1. Raw material stage,

2. Manufacturing stage (design and production),

3. Distribution stage (packaging and transportation),

4. Use stage,

5. End of Life stage (EoL).

The same ISO standard [7] defines that LCA consists of 4 consecutive and interlinked phases:

1. Goal and scope definition,

2. Life Cycle Inventory (LCI),

3. Life Cycle Impact Assessment (LCIA),

4. Interpretation. 
Production technologies and techniques will be analysed in this paper. In accordance with the conducted analysis, possible solutions for energy efficiency improvements, energy savings and use of alternative technologies or techniques will be proposed. Justifications for all of these topics in a single product manufacturing will be provided as well. This Life Cycle Thinking (LCT) approach will be expanded to mass production as well. Differences between these two cases will be pointed out in further text.

Improvements in energy and resource usage, as well as climate change and other environmental impacts are becoming some of the megatrends that are of particular relevance to intralogistics [8]. This research is focused on investigation of the environmental properties of belt conveyors and thus it connects intralogistics with such megatrends as well.

\section{GOAL AND SCOPE OF THE LCA}

This analysis is intended for internal screening at the Faculty of Mechanical Engineering at the Department for Material Handling, Constructions and Logistics, as well as academic population.

One of the objectives of this study is generating an example for educational purpose for students, which can be used for optimization of the environmental properties of the production stage of a belt conveyor. Reason for this is to establish LCT approach among students and academic population.

Functional unit of the product is defined as: Production of the belt conveyor with a mobile, adjustable frame intended for use with steel cord belts, with distance between terminal drums of $\mathrm{L}=1500 \mathrm{~mm}$ and belt width of $B=400 \mathrm{~mm}$.

\section{LCI PHASE}

\subsection{Materials}

All of the raw materials and their amounts used in production of the laboratory belt conveyor are gathered and classified in Table 1.

Table 1. Raw materials in kilograms

\begin{tabular}{|c|c|c|c|c|c|c|}
\hline \multirow{2}{*}{$\begin{array}{c}\text { Raw } \\
\text { Material }\end{array}$} & \multicolumn{2}{|c|}{ Belt conveyor } & \multirow{2}{*}{$\begin{array}{l}\text { Mobile } \\
\text { Frame }\end{array}$} & \multirow{2}{*}{$\begin{array}{c}\text { Skirt } \\
\text { Boards }\end{array}$} & \multirow{2}{*}{$\Sigma \mathrm{A}$} & \multirow{2}{*}{$\Sigma \mathrm{B}$} \\
\hline & $\mathrm{A}^{1}$ & $\mathrm{~B}^{2}$ & & & & \\
\hline $\begin{array}{l}\text { Low-alloyed } \\
\text { Steel }\end{array}$ & 118.0 & 120.5 & 42.0 & 13.0 & 173.0 & 175.5 \\
\hline $\begin{array}{l}\text { Chromium } \\
\text { Steel }\end{array}$ & 0.2 & 0.2 & 3.2 & - & 3.4 & 3.4 \\
\hline Cast Iron & 7.5 & 4.0 & - & - & 7.5 & 4.0 \\
\hline Copper & - & 1.0 & - & - & - & 1.0 \\
\hline $\begin{array}{l}\text { Synthetic } \\
\text { Rubber }\end{array}$ & 12.1 & 12.1 & 2.4 & 0.3 & 14.8 & 14.8 \\
\hline $\begin{array}{l}\text { Plexiglas } \\
\text { (PMMA) }\end{array}$ & 0.6 & 0.6 & - & - & 0.6 & 0.6 \\
\hline Lubricating oil & 0.5 & 0.5 & - & - & 0.5 & 0.5 \\
\hline & & & & & $\mathbf{m}_{\text {tot }} \approx$ & $\begin{array}{l}\approx 200 \\
g\end{array}$ \\
\hline
\end{tabular}

Few components of the belt conveyor are installed as finished products. Therefore, their production has been neglected. For the purpose of a more detailed analysis and inclusion of these parts in the production stage calculations, some assumptions and simplifications have been made and will be discussed in further text.

Conveyor belt or belting is made of synthetic rubber and low-alloyed steel at a ratio of 50:50\%.

Electric Motor (EM) is one of the components which are obtained as a finished product. For the first iteration EM will be modelled as a part made of $5 \mathrm{~kg}$ of cast iron (Scenario A). Further, in accordance with the paper [9], scenario B implies that EM is represented as a product consisted of:

1. Bars and windings made of copper approximately $20 \%$ of the EM total weight

2. Cast iron housing - approximately $30 \%$ of the EM total weight

3. Stator and rotor - magnetic steel parts approximately $50 \%$ of the EM total weight

Therefore, copper content in the EM is estimated to be $1.0 \mathrm{~kg}$, cast iron content $-1.5 \mathrm{~kg}$ and magnetic steel content $-2.5 \mathrm{~kg}$.

From the geared EM, power is transmitted via chain and two sprockets. Chain has a weight of $0.7 \mathrm{~kg}$ per one meter of length.

Mobile conveyor frame is mounted on four wheels $125 \mathrm{~mm}$ in diameter. It is roughly assumed that the wheels are made of low-alloyed steel and synthetic rubber at a ratio of 50:50\%.

Pillow blocks and ball bearing units are finished parts as well, so they are represented as components made of cast iron.

Ball bearings installed in idlers are represented as parts made of hot rolled chromium steel.

Finished parts along with their representation throughout the analysis are given in Table 2.

Table 2. Finished parts and their representation

\begin{tabular}{|l|c|c|c|}
\hline \multicolumn{1}{|c|}{ Part } & Qty. & $\begin{array}{c}\text { Weight } \\
{[\mathrm{kg}]}\end{array}$ & $\begin{array}{c}\text { Total Mass } \\
{[\mathrm{kg}]}\end{array}$ \\
\hline Conveyor Belt & 1 & 24.0 & 24.0 \\
\hline EM, P = 110 W & 1 & 5.0 & 5.0 \\
\hline Wheel, 3477 UFR 125 P62 & 4 & 1.2 & 4.8 \\
\hline Pillow block, UCF 204 & 2 & 0.5 & 1.0 \\
\hline Ball bearing unit, UCT 204 & 2 & 0.8 & 1.6 \\
\hline Idler ball bearing, 609 ZZ & 10 & 0.014 & $\approx 0.2$ \\
\hline Transmission chain & $\approx 1 \mathrm{~m}$ & $0.7 / \mathrm{m}$ & 0.7 \\
\hline
\end{tabular}
Table 1

The values given in Table 2 are already included in

\subsection{Electricity input for production stage}

Machines for the manufacturing process are selected in accordance with the technical drawings and belt conveyor project documentation. They are listed in Table 3.

During the manufacture all processes and procedures are carefully monitored and recorded. Some of the 
processes were neglected since they have no influence on the outcome of the calculations and conducted analysis. Tapping is one of such neglected processes since it is done manually. Assembling is another of the neglected processes since it is done in the laboratory by the laboratory personnel. Painting is also not taken into account.

Table 3. Machines used for manufacturing the belt conveyor

\begin{tabular}{|c|l|c|}
\hline No. & \multicolumn{1}{|c|}{ Machine } & $\begin{array}{c}\text { Power } \\
{[\mathrm{kW}]}\end{array}$ \\
\hline 1 & CNC LASER Cutting Machine & 20 \\
\hline 2 & Hydraulic Press Brakes & 15 \\
\hline 3 & Milling Machine (big) & 4 \\
\hline 4 & Milling Machine (small) $)^{1}$ & 2.5 \\
\hline 5 & Pole Drill & 1.8 \\
\hline 6 & Lathe & 5.5 \\
\hline 7 & Frame Saw & 1.4 \\
\hline 8 & Abrasive Chop Saw ${ }^{2}$ & 2.2 \\
\hline 9 & Hydraulic Swing-Beam Plate Shears & 15 \\
\hline 10 & Hand Grinder & 2 \\
\hline 11 & MIG/MAG Welding Machine & 4 \\
\hline
\end{tabular}

Some processes can be accomplished using different machines. These alterations are also presented in Table 3, as well as Table 4, and they will be explained in further text.

The first iteration of the analysis represents the actual manufacturing process of the belt conveyor and its modules. Therefore, machines marked with numbers 4 and 8 in Table 4 are not included into calculations of electricity consumption during the production stage. These machines are alternative options and will be discussed later.

Table 4. Electricity consumption for production of a particular module per machine in kWh

\begin{tabular}{|c|c|c|c|c|c|c|c|c|c|c|c|}
\hline $\mathrm{kWh}$ & 1 & 2 & 3 & $4^{\star}$ & 5 & 6 & 7 & $8^{*}$ & 9 & 10 & 11 \\
\hline $\mid \begin{array}{l}\text { Belt } \\
\text { Conveyor }\end{array}$ & 6.133 & 3.25 & 22.2 & 13.875 & 0.66 & 58.208 & 3.057 & 74.649 & $9-$ & & 5.053 \\
\hline $\begin{array}{l}\text { Mobile } \\
\text { Carrier } \\
\text { Frame }\end{array}$ & 1.0 & - & 16.667 & 710.417 & - & 8.25 & 2.94 & 2.777 & 7 7. & & 5.333 \\
\hline $\begin{array}{l}\text { Skirt } \\
\text { Boards }\end{array}$ & - & 1.5 & 9.0 & 5.625 & - & - & - & - & 6.0 & & - \\
\hline
\end{tabular}

* Numbers represent machines as marked in Table 3.

- Machines marked with this sign are to be used as alternatives.

\subsection{Transport}

Considering transportation, calculations were based on the fact that some of the components of the belt conveyor were manufactured in Čačak and then transported to the Zaječar for further manufacturing. All other components are made in Zaječar and assembled with those obtained from Čačak. Afterwards, a completely assembled belt conveyor was transported to Belgrade. Traveling distance and transported weights are presented in the Table 5 .
All components of the belt conveyor and additional modules were wrapped only in stretch foil during transportation. Packaging has been neglected.

Table 5. Data related to transportation

\begin{tabular}{|l|l|l|l|}
\hline Traveling route & $\begin{array}{l}\text { Distance } \\
{[\mathrm{km}]}\end{array}$ & $\begin{array}{l}\text { Weight } \\
{[\mathrm{kg}]}\end{array}$ & $\begin{array}{l}\text { Reference } \\
\text { Unit }[\mathrm{tkm}]\end{array}$ \\
\hline Čačak - Zaječar & 220 & 153 & 33.66 \\
\hline Zaječar - Belgrade & 245 & 200 & 49.00 \\
\hline
\end{tabular}

\section{LCIA PHASE}

Impacts on the environment have been calculated using Ecoinvent 3 database and CML-IA baseline V3.02 method. Impact assessment has been done through several iterations.

The first iteration is set as a basic case for further analysis. In accordance with Table 1 and 4, the first case included following materials and processes:

1. Low-alloyed steel, in amount of $173 \mathrm{~kg}$,

2. Chromium steel, in amount of $3.4 \mathrm{~kg}$,

3. Cast Iron, in amount of $7.5 \mathrm{~kg}$,

4. Synthetic rubber, in amount of $14.8 \mathrm{~kg}$,

5. PMMA, in amount of $0.6 \mathrm{~kg}$,

6. Lubricating oil, in amount of $0.5 \mathrm{~kg}$,

7. Electricity, in amount of $160 \mathrm{kWh}$,

8. Transport, freight, in amount of $82.66 \mathrm{tkm}$.

In most of the impact categories, Low-alloyed steel has the biggest influence on the environment, followed by electricity and transport, Table 6 .

Electricity production has the greatest impact in Acidification (see Fig. 4) and Eutrophication impact categories, and realizes big impact on the environment in Global warming, Photochemical oxidation, Fresh water aquatic ecotoxicity and Marine aquatic ecotoxicity impact categories, while it has almost no relevance in Abiotic depletion impact category.

Transport has the greatest impact in the Ozone layer depletion impact category and has a big influence in almost all other baseline impact categories with an exception of terrestrial ecotoxicity, where practically has no influence.

Synthetic rubber impact has relevance in Abiotic depletion, followed by Ozone layer depletion impact category, and has relevant impact in Abiotic depletion (fossil fuels), Global warming, Photochemical oxidation creation, Acidification and Eutrophication categories, while in other impact categories has almost no influence.

Chromium steel has big impact in Human toxicity and Fresh water aquatic ecotoxicity categories, relevant impact in Abiotic depletion, Marine aquatic ecotoxicity and Terrestrial ecotoxicity category, while in other impact categories it can be neglected.

Cast iron has relevant impact on the environment only in Terrestrial ecotoxicity impact category. In other impact categories it can be neglected. 


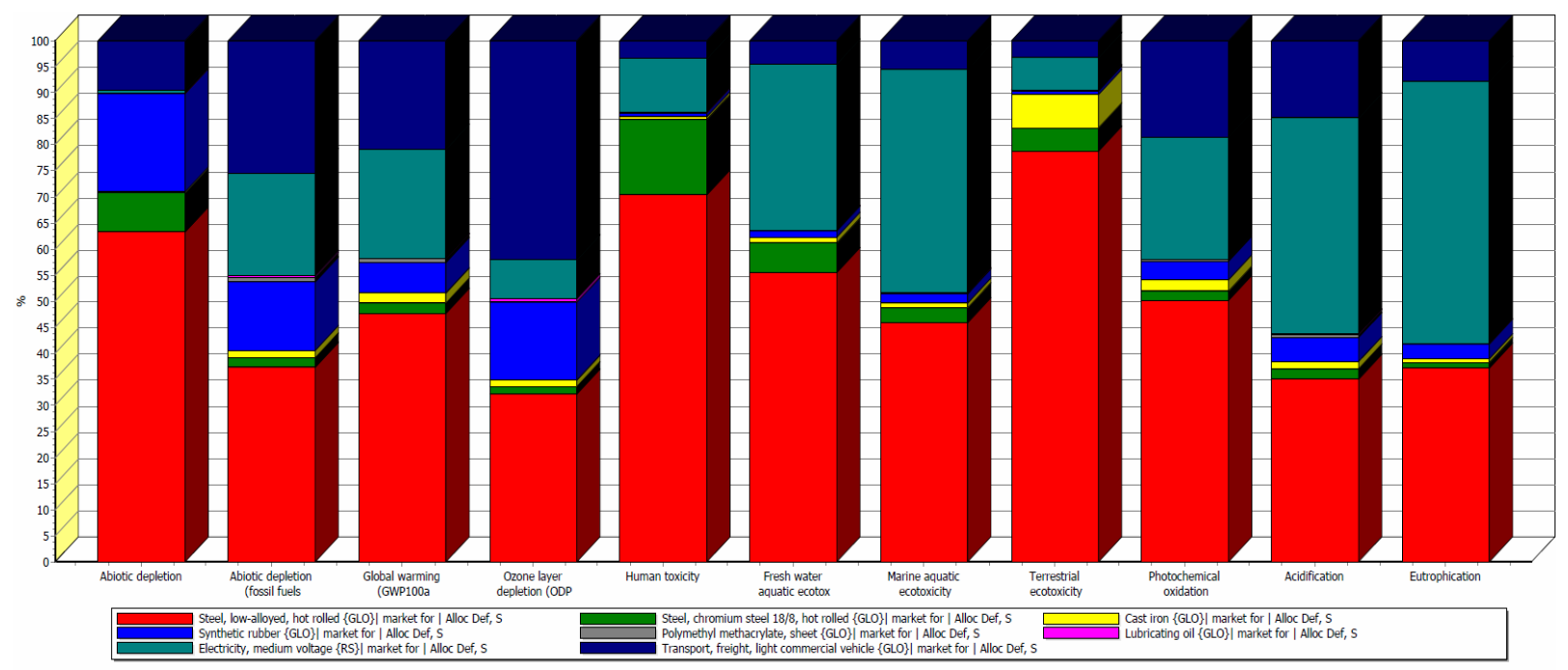

Analying 1 p Laboratory Eelt Conveyor it.01';
Metrod: CML-IA baseline V3.02 / EV25/Characterization / Excluding infiastucture processes

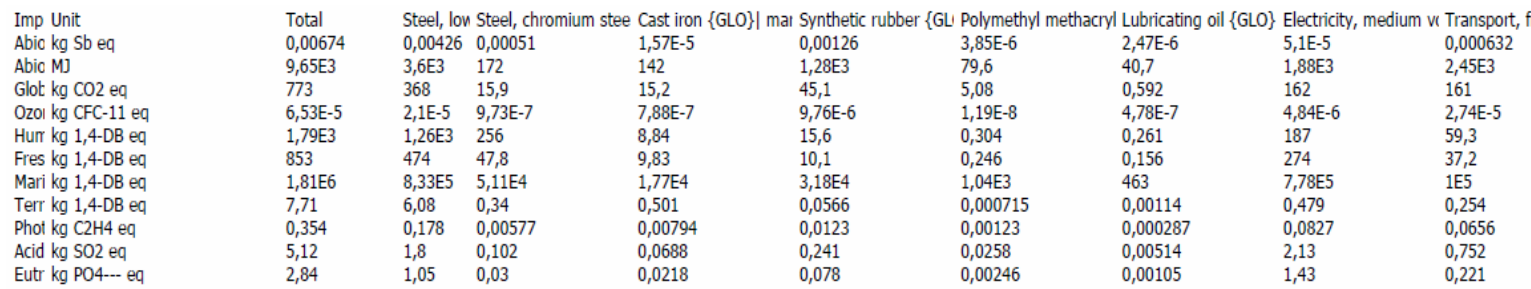

Figure 3. Characterization of the first iteration. Chart and table representation

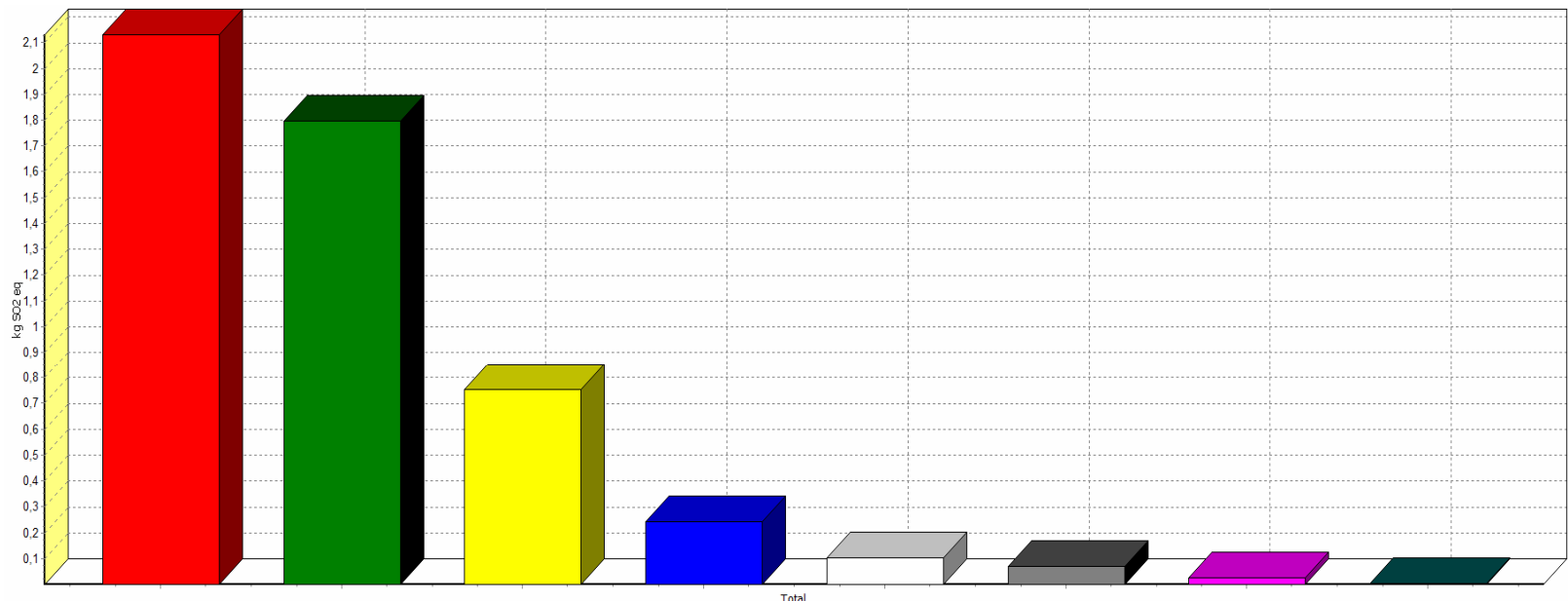

Electrichy, medium voltage $\{$ RSS\} merket for I Alloc Def, $\mathrm{S}$

Analyzing 1 p 'Laboritory Belt Conveyor it.01';
Method: CML-IA baseline V3.02 / EV25/ Cha

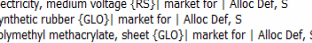

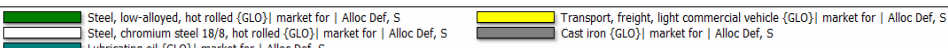

Figure 4. Characterisation chart of Acidification Potential (AP) impact category for iteration 1

Table 6. Contribution of the individual materials and processes to given impact categories

\begin{tabular}{|c|c|c|c|c|c|c|c|c|c|c|c|}
\hline $\begin{array}{l}\text { Material or } \\
\text { process }\end{array}$ & $\mathrm{ADP}$ & $\begin{array}{c}\text { ADP } \\
\text { (fossil fuels) }\end{array}$ & GWP & ODP & HTP & FWAEP & MAEP & TEP & POCP & $\mathrm{AP}$ & EP \\
\hline Low-alloyed steel & 1 & 1 & 1 & 2 & 1 & 1 & 1 & 1 & 1 & 2 & 2 \\
\hline Chromium steel & 4 & 5 & 5 & 5 & 2 & 3 & 4 & 4 & 6 & 5 & 5 \\
\hline Cast iron & 6 & 6 & 6 & 6 & 6 & 6 & 6 & 2 & 5 & 6 & 6 \\
\hline Synthetic rubber & 2 & 4 & 4 & 3 & 5 & 5 & 5 & 6 & 4 & 4 & 4 \\
\hline PMMA & 7 & 7 & 7 & 8 & 7 & 7 & 7 & 8 & 7 & 7 & 7 \\
\hline Lubricating oil & 8 & 8 & 8 & 7 & 8 & 8 & 8 & 7 & 8 & 8 & 8 \\
\hline Electricity & 5 & 3 & 2 & 4 & 3 & 2 & 2 & 3 & 2 & 1 & 1 \\
\hline Transport & 3 & 2 & 3 & 1 & 4 & 4 & 3 & 5 & 3 & 3 & 3 \\
\hline
\end{tabular}


PMMA (Polymethyl methacrylate also known as Plexiglas) and lubricating oil has almost no influence and they can be neglected. For example, PMMA has the greatest impact in Abiotic depletion (fossil fuels) category, but its contribution is below $1 \%$. However, one should have in mind that, in this case, these materials appear in very small amounts. If they appeared in larger amounts, these materials could not be neglected because they have a significant impact on the environment even in small quantities.

In Table 6 impact categories are represented with usual abbreviations. Numbers from 1 to 8 are assigned to the materials or processes in correlation with their influence on given impact category. Fields with grey numbers are excluded by applying a "cut-off" rule of $5 \%$. The "cut-off" rule is explained in [4].
It is pointed out that low-alloyed steel, electricity production and transport have the biggest impacts.

In attempt to conduct a more precise analysis, the EM is considered as proposed in the scenario B. Even though copper occurs in a quantity of only $1 \mathrm{~kg}$, its impact on the environment is not negligible, see Fig. 5.

Copper has the greatest impact in Abiotic depletion category, Fig. 6.

Application of the "cut-off" rule of $5 \%$ does not exclude impact of the copper from the majority of impact categories.

This draws attention to the fact that it is very important to adequately analyse the composition of a product, especially if there is a possibility it contains problematic substances.

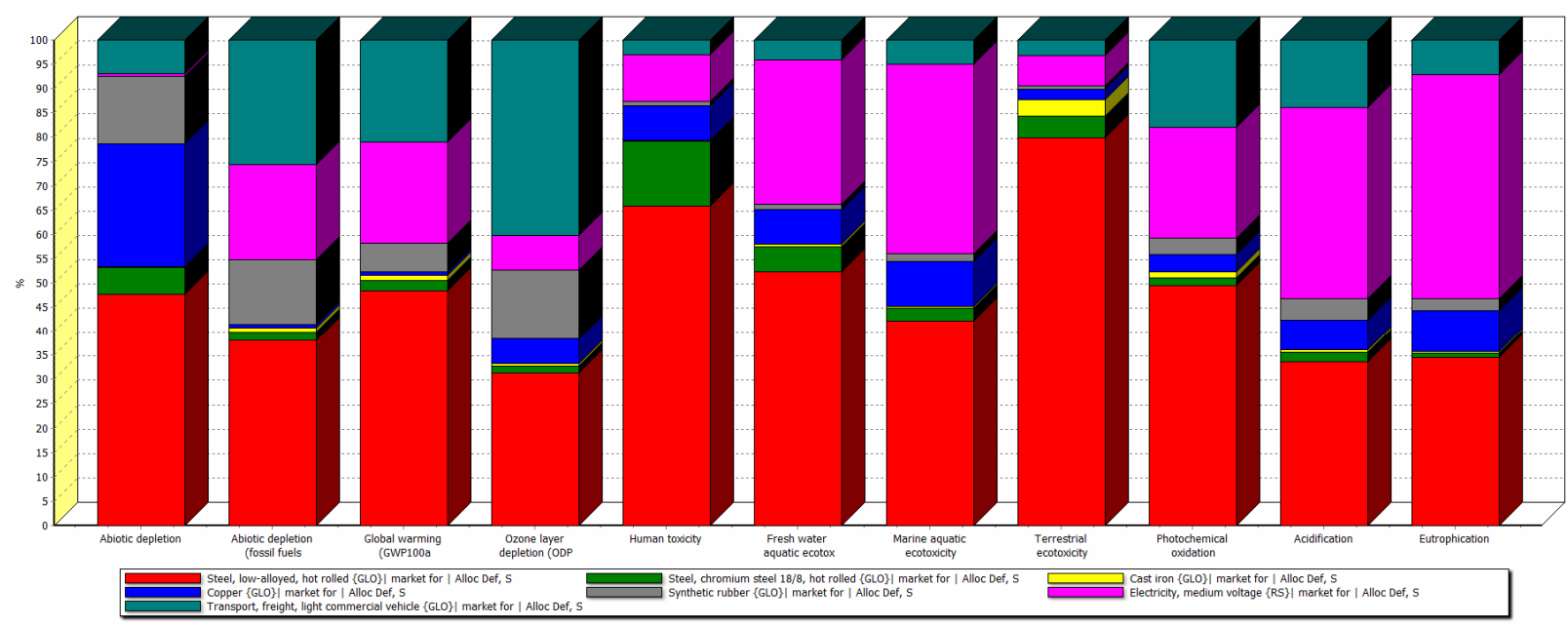

Anolyzing 1 P 'Laboratory Belt Conveyor it.03';
Method: CML-AA baseline V3.02 / EU25 / Char

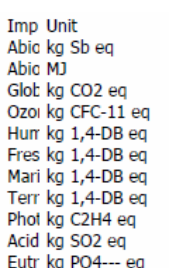

$\begin{array}{lll} & & \\ \text { Total } & \text { Steel, lon Steel, ch } \\ 0,00907 & 0,00433 & 0,00051 \\ 9,58 E 3 & 3,65 \mathrm{E} 3 & 172 \\ 771 & 374 & 15,9 \\ 6,82 \mathrm{E}-5 & 2,13 \mathrm{E}-5 & 9,73 \mathrm{E}-7 \\ 1,94 \mathrm{E} 3 & 1,28 \mathrm{E} 3 & 256 \\ 921 & 481 & 47,8 \\ 2 \mathrm{E} 6 & 8,45 \mathrm{E} 5 & 5,11 \mathrm{E} 4 \\ 7,72 & 6,17 & 0,34 \\ 0,364 & 0,18 & 0,00577 \\ 5,42 & 1,82 & 0,102 \\ 3,1 & 1,07 & 0,03\end{array}$

$\begin{array}{ll} & \\ 11 & \\ 8,38 \mathrm{E}-6 & \\ 76 & \\ 76 & 0,00229 \\ 8,11 & 70,3 \\ 4,2 \mathrm{E}-7 & 5,44 \\ 4,71 & 3,44 \mathrm{E}-6 \\ 5,24 & 139 \\ 9,45 \mathrm{EE} 3 & 65,8 \\ 0,267 & 1,84 \mathrm{E} 5 \\ 0,00424 & 0,155 \\ 0,0367 & 0,0132 \\ 0,0116 & 0,333 \\ & 0,265\end{array}$

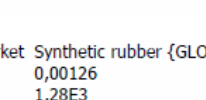

$$
\begin{aligned}
& 0,00126 \\
& 1,28 \mathrm{E} 3 \\
& 45,1
\end{aligned}
$$

45,1
$9,76 \mathrm{E}-6$
15,6
10,1

15,6
10,1
$3,18 \mathrm{E} 4$

10,1
$3,18 \mathrm{E} 4$
0,0566

0,0566

0,0123
0,078

$\begin{array}{ll}\text { O) Electricity, medium volt Transport, freight, light } \\ 5,1 \mathrm{E}-5 & 0,000632 \\ 1,88 \mathrm{E} 3 & 2,45 \mathrm{E} 3 \\ 162 & 161 \\ 4,84 \mathrm{E}-6 & 2,74 \mathrm{E}-5 \\ 187 & 59,3 \\ 274 & 37,2 \\ 7,78 \mathrm{E} 5 & 1 \mathrm{E} 5 \\ 0,479 & 0,254 \\ 0,0827 & 0,0656 \\ 2,13 & 0,752 \\ 1,43 & 0,221\end{array}$

Figure 5. Characterization of the second iteration. Chart and table representation

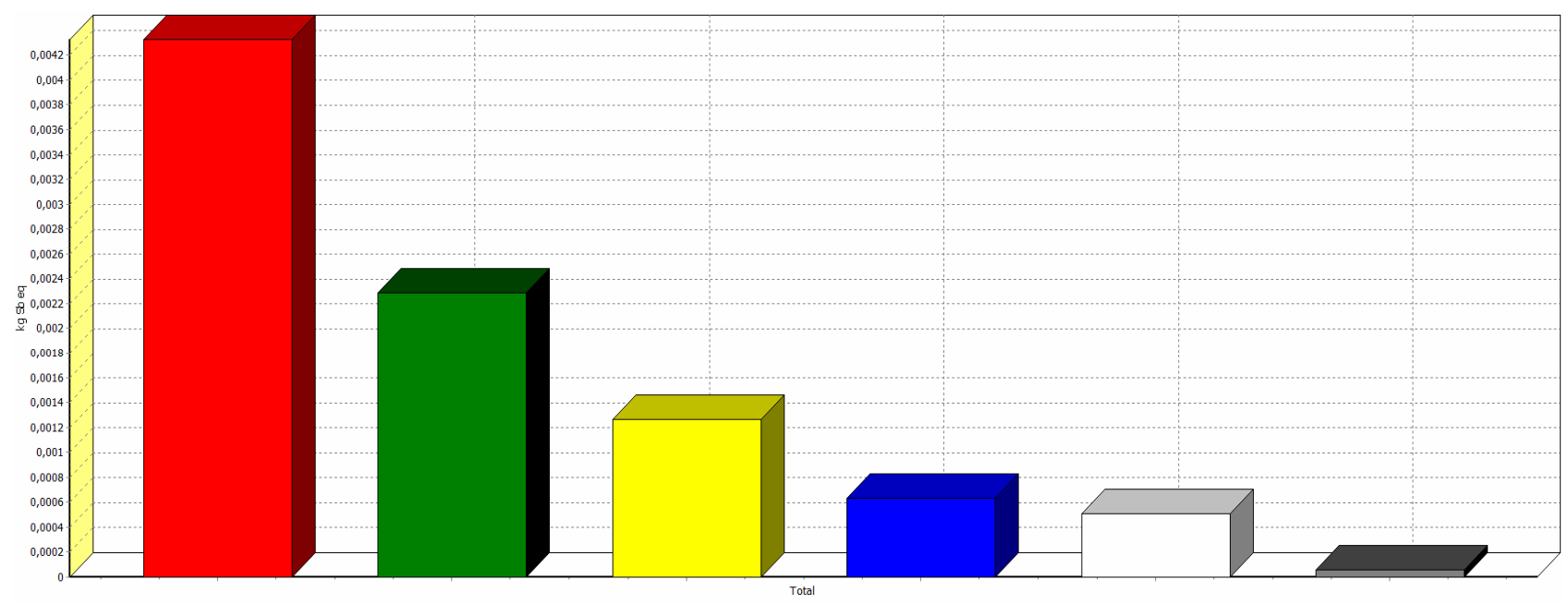

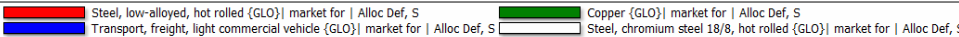

Figure 6. Characterisation chart of Acidification Potential (AP) impact category for iteration 2 with applied "cut-off" rule of $5 \%$ 


\section{DISCUSSION}

Having in mind previously presented data and the fact that this paper deals with the production stage of a belt conveyor, it is obvious that major environmental improvements can be achieved by reducing the electricity consumption and transportation. There are several ways to accomplish this goal. Some of them will be proposed in further text.

Electricity consumption could be reduced by using machines that consume less energy. Specifically in this case, big milling machine could be replaced with a small one. In order to avoid using hand grinder for post processing welds, they can be done in better quality. These two actions can save almost $30 \mathrm{kWh}$ of electric energy, see Figures 7 and 8.
When comparing Figures 3 and 7, one can notice the difference between the charts, which is more easily observed in their respective tables. When comparing Figures 4 and 8 , it can be noticed that the electricity has a lower impact on Acidification and that its contribution is not the greatest in this case.

Manufacturing bigger parts using a small milling machine requires more operations in comparison with the big milling machine. This fact is reflected on the increased time required for the manufacturing of these parts, and decreased machining quality. Moreover, the increased number of working hours results in higher expenses for workers' wages. From the economic standpoint, this is a less favourable option, but from the ecological aspect this option is more favourable.

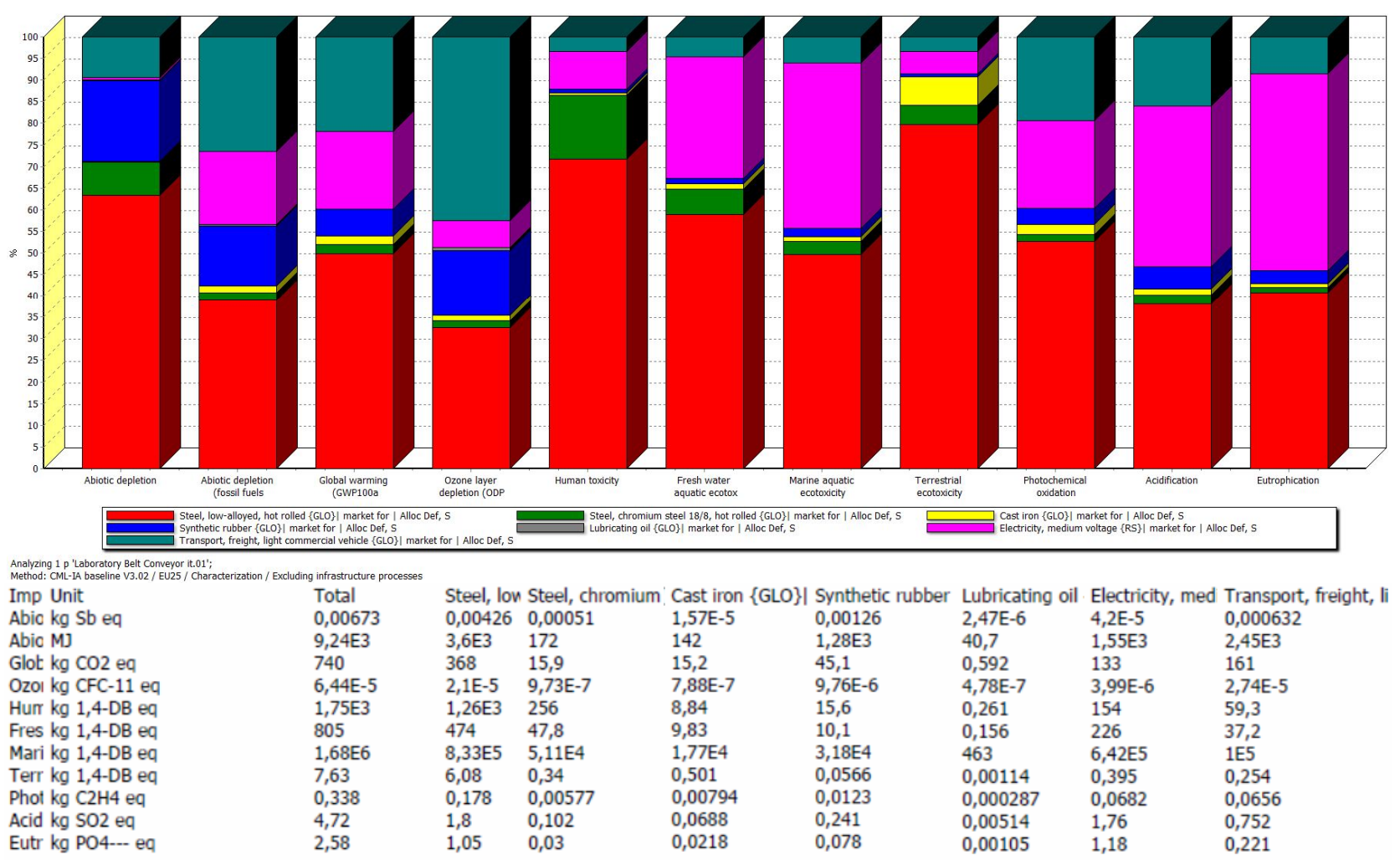

Figure 7. Characterization of the third iteration. Chart and table representation

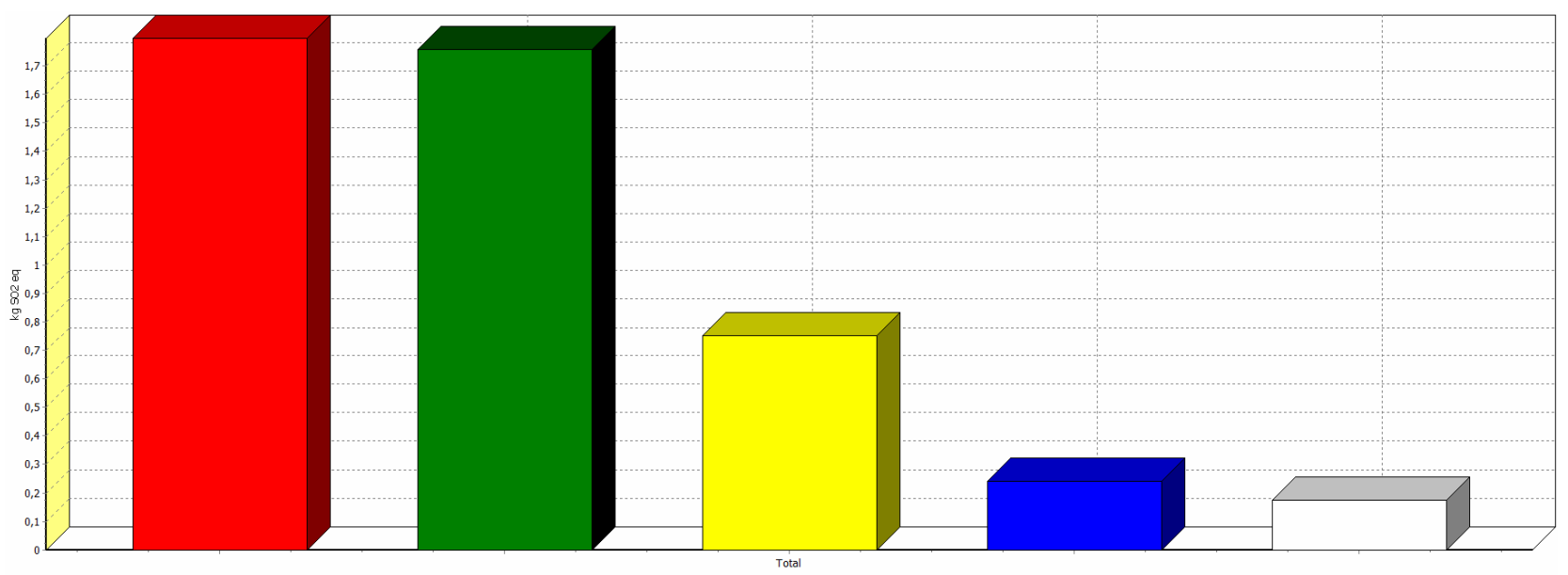


Working hour costs are not taken into account, since this is reflected only on the economic aspect. From the environmental point of view this issue can be neglected because it would not affect the result of the analysis.

In accordance with Table 4 it can be noticed that substitution of the frame saw with an abrasive chop saw is not justified. It would even increase the consumption of electricity in this case, but this does not exclude the possibility that in some other case savings could be achieved.

Considering energy efficiency improvement, frame saw can be used in a way that one can stack together more than one part for sawing at once.

For terms such as energy efficiency and energy saving, as well as sustainability, sustainable development and Ecodesign, refer to [4], [10] and [11].

Regarding larger production volumes and mass production, certain manufacturing processes have to be reconsidered. For example, tapping has to be done using machines, such as a pole drill.

When considering reduction of costs in large-scale production, development of special accessories for certain processing operations should be taken into account. This way, machines that are large energy consumers can be excluded from the production stage and they could be substituted with machines that consume less energy. For example, drilling operations can be done using hand tools and patterns or machines with a smaller working area.

Considering the transport, in this particular case reduction can be made by moving complete production from Zaječar to Čačak. This way a trip from Čačak to Zaječar is avoided, and only transport from Čačak to Belgrade is needed. Moreover, such trip would be shorter, with a transport of $27.20 \mathrm{tkm}$ in total. This way, the impact of transport on the environment has been significantly reduced.

\section{CONCLUSION}

It is concluded that impacts on the environment from the production of the laboratory belt conveyor largely depend on electricity consumption and transport of the finished product. Although the biggest impact on the environment originates from low-alloyed steel, the electricity production and transport of the finished belt conveyor are related to manufacturing stage, and thus relevant for this LCA.

The second iteration has shown that copper as well realizes significant impact on the environment, although it is present in a small quantity $(0.5 \%$ of the total weight of the considered modules). This remark suggests that if the system contain components that are built in as a finished products, it is important to investigate their composition in order to determine if any of environmentally problematic substances are present. In order to conduct a proper and thorough LCA, inclusion of such parts and materials is very important.

Process and auxiliary materials are often a hazardous substances. Usually, the nature and amount of these additional materials should be inspected. In this case specifically, there were no many process and auxiliary materials so they were excluded from the analysis.

In this particular analysis smaller milling machine was proposed as alternative option. Its utilisation would reduce energy consumption, but on the other hand, it would increase production time. From the economy standpoint, increasing of production time reflects in higher expenses for workers' wages, while from the environmental point of view it could be beneficial as long as it results in environmental impact reduction.

Considering alternative technologies and solutions, one should have in mind that not every alternative is a better solution. What appears to be a better solution at first sight does not necessarily mean that it really is. Alternative solutions should be carefully considered.

Although in this particular case packaging was irrelevant, in other cases it should be taken into consideration. It is recommended to use packaging only when it is necessary and as small as possible, since packaging becomes waste as soon as the product is delivered.

Automatization of processes, use of patterns etc. should be considered for larger production series.

In accordance with discussion and conclusion, final remarks could be pointed out, as proposed solutions:

- Alternative machines,

- Alternative travel routes,

- Avoid unnecessary trips,

- Carefully choose auxiliary materials,

- Consider packaging,

- Avoid unnecessary materials (requires careful consideration),

- Avoid unnecessary processes (such as post processing of welds).

\section{ACKNOWLEDGMENT}

This work is a contribution to the Ministry of Education, Science and Technological Development of Republic of Serbia funded project TR 35006.

\section{REFERENCES}

[1] Đorđević, M., Zrnić, N., Bošnjak, S.: Laboratory Test Rig for Nondestructive Inspection of Steel Cord Belts, in: Proceedings of the $9^{\text {th }}$ International Conference "Heavy Machinery - HM 2017", 28.06.-01.07.2017, Zlatibor, Session A: pp. 61-68.

[2] Đorđević, M., Zrnić, N. and Bošnjak, S.: Resolving a Laboratory Test Rig Belt Misalignment Issue, in: Proceedings of the $22^{\text {nd }}$ International Conference MHCL'17, 04.-06.10.2017, Belgrade, pp. 63-66.

[3] SimaPro Life Cycle Analysis version 8.0.4.7 (software) by Pre Consultants.

[4] Đorđević, M., Zrnić, N. and Bošnjak, S.: LCA of a Belt Conveyor and its Application, in: Borut, J. (Ed.): Next Generation Logistics: Technologies and Application, Scientific Monograph, Scientific Publishing Hub, Chapter 8, pp. 175-197, 2017.

[5] Zrnić, N. and Đorđević, M.: Ecodesign: Sustainable Product Development, (in Serbian: 
Dizajn i Ekologija: Održivi razvoj proizvoda), University of Belgrade, Faculty of Mechanical Engineering, ISBN: 978-86-7083-772-0, Belgrade, Serbia, 2012.

[6] Đorđević, M., Zrnić, N. and Pantelić, M.: Simplified Life Cycle Assessment of a Return Belt Conveyor Idler, in: Proceedings of the $11^{\text {th }}$ International Conference on Accomplishments in Electrical and Mechanical Engineering and Information Technology, DEMI 2013, 30.05.01.06.2013, Banja Luka, pp. 201-206.

[7] EN ISO 14040: 2006.

[8] Kartnig, G., Grösel, B. and Zrnić, N.: Past, Stateof-the-Art and Future of Intralogistics in Relation to Megatrends, FME Transactions, Vol. 40, No. 4, pp. 193-200, 2012.

[9] Đorđević, M., Zrnić, N. and Jerman, B.: Simplified Life Cycle Assessment of a Belt Conveyor Electric Motor, in: Proceedings of the $14^{\text {th }}$ International Conference "Research and Development in Mechanical Industry - RaDMI 2014”, 18.21.09.2014, Vrnjačka Banja, ISBN: 978-86-6075047-3, pp. 671-678.

[10] Humpl, D. and Starkl, F.: (2010). The contributions of logistics to enhance energy efficiency in freight transport, in: Proceedings of the $21^{\text {st }}$ Annual
Conference POMS, 07.-10.05.2010, Vancouver, p. 20.

[11]Langerholc, M., Zrnić, N., Đorđević, M. and Jerman, B.: Conveyor Design Optimization as the Provision of Sustainability, Technical Gazette, Vol. 20, No. 5, ISSN: 1330-3651, pp. 837-846, 2013.

\section{АНАЛИЗА ФАЗЕ ПРОИЗВОДЫЕ ПРИ ПРОЦЕНИ ЖИВОТНОГ ЦИКЛУСА ЛАБОРАТОРИЈСКОГ ТРАКАСТОГ ТРАНСПОРТЕРА}

\section{М. Ђорђевић, Г. Младеновић, Н. Зрнић С. Бошњак}

Спроведена је процена животног циклуса малог тракастог транспортера. Анализирана је фаза производње са аспеката утицаја на животну средину и потрошње енергије. Највећи утицај на животну средину у већини категорија утицаја за основни модел категорија утицаја потиче од производње нисколегираних челика и потрошње електричне енергије током фазе производње, праћен утицајем транспорта. У раду су такође предложени начини уштеде енергије у производној пракси уз примену адекватних технологија. 